Apidologie, 1976, 7 (3), 197-207.

\title{
THE FINE STRUCTURE OF THE WAX GLAND OF THE HONEY BEE (APIS MELLIFERA L.)
}

\author{
Malcolm T. SANFORD and Alfred DIETZ \\ Department of Entomology, University of Georgia, Athens, Georgia 30602 (U.S.A.)
}

\section{SUMMARY}

An electron microscopic study was initiated to elucidate the ultrastructure of the wax gland in an actively wax secreting worker honey bee. The investigation showed that the cuticle is penetrated by bundles of fibers or pores. The epithelial cells of the wax gland possess tubular invaginations filled with material which accummulates below the cuticle. The numerous mitochondria, microtubules and convolutions located in the cells suggest that this epithelium functions in either the transport or the concentration of substances during bees wax synthesis rather than storage for release associated with secretory cells.

Whether the pore canals are made up of microfilaments or microtubules is still uncertain for the morphology seems to vary in different preparations depending on the fixation procedure. Our findings support the microtubule interpretation, especially since both the microtubules of the underlying epithelium and the wax filaments measure about $230 \mathrm{~A}$ in diameter. The microtubular structure of the wax gland cell appears to function as a cytoskeleton.

Secretion of wax to protect against water loss through the integument is a common phenomenon in insects. The honey bee, in addition to this protective layer, also produces wax used in the construction of combs. Beeswax is secreted by worker bees on paired, smooth, oblong areas, called wax mirrors, located ventrally on abdominal segments four through seven.

On the dorsal side of each wax mirror is a layer of epithelial tissue called the wax gland. This epithelium is seen to fluctuate in development in individual workers dictated by various factors including the age of the secreting bee, its nutritional state and the colony's need for wax production. As secretory activity increases, the cells of the wax gland become tall and slender (Dreiling, 1903).

Production of beeswax in the honey bee is a process whereby many thin layers of wax are deposited on the wax mirror until a scale results (DiETz and 
Humphreys, 1970). The mechanism by which beeswax penetrates the cuticle to form the layers of the scale has been the subject of several investigations. Dreiling (1905) believed that pores were responsible for transporting the wax to the exterior. Rieman (1952), however, using an electron microscope, could discern no pores, but believed the wax flowed out between fibers he observed in the wax mirrors. Locke (1961) was able to resolve what he called pore canals made up of wax filaments which penetrated the cuticle. The pore canals, however, did not appear to pass through the thin epicuticular layer of the integument which consists of an oriented lipid layer overlain by a layer of cuticulin.

Beeswax is a complex substance made up of esters, fatty acids and hydrocarbons (Piek, 1964; Tullock, 1970; Vergeron, 1967). Piek (1964) hypothesized that labelled acetate is converted into the constituents of beeswax by the oenocytes and fat cells which are found beneath and are closely associated with the wax gland. Locke (1961) was able to locate an esterase, which he considered could effect wax synthesis in the honey bee cuticle as well as in the underlying epithelium, but he gave no conclusion as to the function of the epithelial layer in wax elaboration.

Because the role of the wax gland in beeswax synthesis and secretion remains unclear, a study of the fine structure of the epithelial layer was initiated. The purpose of this paper is to describe the ultrastructure of the wax gland found in the honey bee. The results of the study provide more insight into the wax gland's role in beeswax synthesis and secretion. The structure of the pore canals which penetrate the cuticle is also re-examined.

\section{MATERIALS AND METHODS}

Wax mirrors and the underlying epithelium of worker honey bees actively secreting wax were dissected and immersed for two hours in Karnovsky's high osmolality fixative (KARnovsky, 1965). The tissue was diced into blocks one millimeter square or less, further fixed in $2 \%$ osmium tetroxide in $1 \mathrm{M}$ cacodylate buffer (pH 7.2) for one hour, and dehydrated through a series of ascending dilutions to $100 \%$ ethanol. The blocks of tissue were infiltrated with Spurn (1969) low viscosity embedding medium using the following schedule : one to one embedding medium and $100 \%$ ethanol for twenty-four hours, $100 \%$ embedding medium for twenty-four hours, and a change of medium for eight hours at $70^{\circ} \mathrm{C}$ to effect polymerization.

Silver and gold sections were cut on a Reichert OmU2 ultramicrotome, placed on copper grids of various mesh sizes and stained for one hour in a saturated solution of uranyl acetate in methanol followed by five minutes in lead citrate (REynoLDS, 1963). Grids were examined on the Philips EM 200 and RCA EMU 3E transmission electron microscopes.

\section{RESULTS}

The cuticle in longitudinal section is seen as a series of lamella comprising the endocuticle covered by a thin epicuticle (Fig. 1). The width of the procuticle consistently measures about $1.8 \mathrm{um}$. At intervals the cuticle is penetrated 
by what have been called pore canals which consist of bundles of wax filaments (LосKE, 1961). The characteristic whorl of the pore canals is due to the cuticle being laid down in lamellae of different orientation (Neville, 1970).

In cross section, the pore canals appear as slits in the cuticle and the wax filaments look tubular, measuring about $230 \mathrm{~A}$ in dianeter (Fig. 2). It is difficult to determine whether the pore canals and their filaments do indeed extend through the cuticle. At the cuticular surface, the pore canals are indistinct and a definite interpretation is not possible.

The underlying epithelial layer in longitudinal section is about $40 \mu \mathrm{m} \mathrm{high}$. The cells of this layer are columnar with large distinct nuclei and they are supported by a basement membrane. The cytoplasm contains an abundance of mitochondria, microtubules and rough endoplasmic reticulum (Fig. 3).

The mitochondria are pleomorphic with tubular shaped cristae, and in many instances are oriented parallel to the rough endoplasmic reticulum and the microtubules. The microtubules are extremely long and numerous in some sections; they also appear in cross and longitudinal section irrespective of the cell's orientation. The rough endoplasmic reticulum and many polyribosomes are dispersed throughout the cell. There is a characteristic lack of smooth endoplasmic reticulum in the cells of the wax gland.

The cells of the wax gland appear to have tubular invaginations from the apical surface which approach the cell base. Other invaginations can also be seen from the cells' base which are lined with a thin basal lamina. The apical invaginations are filled with a granular material; whereas, those arising from the cell base contain an amorphous clear substance (Fig. 4). The granular material found in the apical invaginations becomes concentrated just below the cuticle (Fig. 5).

The nuclei of the wax gland cells are irregular in shape and some contain several nucleoli. Little heterochromatin is found lining the nuclear envelope and many nuclei have extensive invaginations of cytoplasm. Nuclear pores are also prominent (Fig. 6).

A developed Golgi apparatus and vesicles or granules associated with packaging secretory material for export cannot be discerned. Desmosomes (macula adherens) and apparent tight junctions (zonula occludens) are found in the plasma membranes between adjacent cells of the wax gland epithelium (Fig. 7 and 8). Septate desmosomes, present in many arthropod tissues, are not observed in the wax gland epithelium and tracheoles are seen to penetrate the extracellular space.

\section{DISEUSSION}

Examination of the fine structure of the wax gland indicates that its function in heeswax secretion is either strictly transport or concentration of 
substances rather than packaging them for release as is the case with many secretory cells. The apparent lack of a developed Golgi apparatus and associated vesicles supports this hypothesis; it is also consistent with the observations by Pier (1964) that the constituents of beeswax are synthesized in the fat cells and oenocytes underlying the wax gland, and with the localization of an esterase (Locke, 1961) throughout the epithelium beneath the cuticle.

Analysis of the results of this study suggests a number of ways that the wax gland epithelium may function. Wax precursors from the oenocytes and fat cells may be incorporated into the wax gland, concentrated and then pumped into the extracellular space. This concept is supported by the difference in contents exhibited by the apical and basal invaginations which suggests that they are not continuous. Alternatively, materials may be taken up exclusively in the extracellular space or perhaps pumped into the cell and out again at different cell levels. During wax synthesis the wax gland cells may add materials to those taken across the basement membrane or take materials away before the wax, or its immediate precursor, is secreted through the pore canals. The actual site of final beeswax elaboration has not been established.

Whether the pore canals are made up of microfilaments or microtubules is still in question for their morphology seems to vary in different preparations depending on fixation procedure. The results presented here support the microtubule interpretation, especially since both the microtubules of the underlying epithelium and the wax filaments measure about $230 \mathrm{~A}$ in diameter.

LOCKE (1961) believed that the bundles of wax filaments were extracellular in nature because he saw invaginations of the plasma membrane in longitudinal section. The plasma membrane below the cuticle was not observed in this study probably because of differences in fixation procedure. The fact that transport may occur in the extracellular space in wax gland epithelium is not inconsistent with other descriptions of insect epithelial tissue involved in water and ion transport, and overlain with cuticle (COPELAND, 1964; Gupta and Berridge, 1966; Smith, 1968; Wichard and Komnick, 1971). Whether the transport mechanism in the wax gland is similar to that of water and ion transporting epithelia, however, is not clear.

The numerous mitochondria present in wax gland cells no doubt provide the power for transport across the epithelial layer and/or plasma membrane similar to the " mitochondrial pump " described by Copeland (1964). Although it is not possible to state where the wax or its precursors might enter the extracellular space, the existence of what appear to be tight junctions would lend support to an extracellular entry apical to these junctions. More 
study, however, is required to elucidate the junctional morphology of the wax gland and its functional significance.

Complex folds above the basal lamina have been described in other epithelial transport tissue (Lake et al., 1973; Sмith, 1968; Tадвот et al., 1972). The function of such foldings in wax gland epithelium is not known, but it may be involved in micropinocytosis or ion transport similar to the a standing gradient flow system » described by Diamond and Bossert (1967) and Diamond (1971 a; 1971 b) for water and ion transporting epithelia.

The function of the basal lamina observed in the wax gland is also uncertain. It has been suggested, however, that the basal lamina, at least in Malpighian tubule cells, may act as a permeability filter preventing large blood protein molecules from entering the extracellular space (BERRIDGE and Oschman, 1969). There is additional evidence that the basal lamina of active transport tissue may vary considerably in its permeability (TALBOT et al., 1972).

The microtubular structure of the wax gland cell presumably functions as a cytoskeleton. The fact that microtubules in any one section can be seen in cross, tangential and longitudinal section lends credence to a cytoskeletal concept. The microtubules may also function as aligning centers for the mitochondria and rough endoplasmic reticulum as discussed by WITK us et al. (1969).

Received for publication in March 1976.

Reçu pour publication en mars 1976.

\section{ACKNOWLEDGEMENT}

We would like to thank Drs. Walter J. Humphreys and J. Munnels, University of Georgia, for extending invaluable assistance to the authors during the course of this investigation.

\section{ZUSAMMENFASSUNG}

DIE FEINSTRUKTUR DER WAGHSDRÜSE BEI DER HONIGBIENE (Apis mellifica L.)

Zur besseren Kenntnis der Ultrastruktur der Wachsdrüse einer aktiv Wachs sezernierenden Honigbiene wurde eine elektronenmikroskopische Untersuchung vorgenommen. Diese Untersuchung zeigte, dass die Kutikula von Faser- und Porenbündeln durchzogen ist. Die Epithelzellen der Wachsdrüse besitzen röhrenförmige Einstülpungen, die mit einer sich unter der Kutikula anhäufenden Substanz gefüllt sind. Die zahlreichen Mitochondrien, Mikrokanälchen und Einbuchtungen in den Zellen deuten darauf, dass dieses Epithelium eher den Transport oder die Konzentration von Substanzen während der Entstehung des Bienenwachses bewirkt, als dass es zusammen mit den sekretorischen Zellen für die Materialspeicherung sorgt. 
Ob die Porenkanäle aus Mikrofilamenten oder Mikroröhren bestehen, ist ungewiss; denn ihre Gestalt scheint in verschiedenen Praiparateil - je nach Fixierungivorgang — unterschiedlich zu sein. Unsere Ergebnisse stützen die Mikroröhren-lnterpretation, besonders, da sowohl die Mikroröhren des darunterliegenden Epitheliums als auch die Wachsfilamente einen Durchmesser von ungefähr $230 \mathrm{~A}$ haben. Die Mikroröhren-Struktur der Wachsdrüsenzelle scheint als Zellskelett zu fungieren.

\title{
RÉSUMÉ
}

\author{
Ultrastructure de LA GLANDE Cirière CHEz L'ABEILle \\ (Apis mellifica L.)
}

On a mené une étude en microscopie électronique pour avoir une meilleure connaissance de l'ultrastructure de la glande cirière chez une ouvrière d'abeille en période de secrétion cirière. Cette étude a montré que des faisceaux de fibres et des groupes de pores traversaient la cuticule. Les cellules épithéliales de la glande cirière possèdent des invaginations tubulaires remplies par la matière qui s'accumule sous la cuticule. La présence de nombreuses mitochondries, de microtubules et de circonvolutions localisées dans la cellule suggère que cet épithélium joue un rôle soit dans le transport, soit dans la concentration de substances au cours de la synthèse de la cire par les abeilles, plutôt que dans le stockage en vue d'une libération ultérieure, associé avec les cellules secrétrices.

On n'a pu déterminer si les canaux des pores étaient constitués de microfilaments ou de tubules, car la morphologie semblait varier suivant les préparations en fonction du mode de fixation. Nos résultats corroborent l'interprétation par les microtubules, puisque en particulier les microtubules de l'épithélium sous-jacent tout comme les filaments de cire ont un diamètre d'environ $230 \mathrm{~A}$. La structure microtubulaire de la cellule de la glande cirière semble correspondre à un cytosquelette.

\section{REFERENCES}

Berridge M. J. and J. L. Oschman, 1969. - A structural basis for fluid secretion by Malpighian tubules. Tissue and Cell. 1 : 247-272.

Copeland D. E., 1964. - A mitochondrial pump in the cells of the anal papillae of mosquito larvae. J. Cell. Biol. $23: 253-263$.

Diamond J. M., 1971 a. - Water-solute coupling and ion selectivity in epithelia. Phil. Trans. Roy. Soc. Lond. B $262: 141-151$.

Diamond J. M., 1971 b. - Standing-gradient model of fluid transport in epithelia. Fed. Proc. $30: 6-13$.

Dramond J. M. and W. H. Bossert, 1967. - Standing-gradient osmotic flow. A mechanism for coupling of water and solute transport in epithelia. J. Gen. Physiol. $50: 2061-2083$.

Dietz A. and W. J. Humpureys, 1970. -- Scanning electron microscopy study of the structure of honey bee wax scales. J. Georgia Entomol. Soc. 5 : 1-6.

Dreyling L., 1903. - Über die wachsbereitenden Organe der Honigbiene. Zool. Anz. 26 : 710 715.

Dreyling L., 1905. - Die wachsbereitenden Organe bei den gesellig lebenden Bienen. Zool. Jahrb. (Anat.) $22: 289-330$.

Gupta B. L. and M. J. Berridge, 1966. - Fine structural organization of the rectum in the blowfly, Calliphora erythrocephala (Meig.) with special reference to connective tissue, tracheae and neurosecretory innervation in the rectal papillae. J. Morph. $120: 23-81$. 
KARNovsKY M. J., 1965. - A formaldehyde-glutaraldehyde fixative of high osmolality for use in electron microscopy. J. Cell. Biol. $27: 137 \mathrm{~A}$.

LAKE P. S., SWAIN R. and J. E. ONG, 1973. - The ultrastructure of the fenestra dorsalis of the syncarid crustaceans $A$. helonomous and $A$. hickmaini. $Z$. Zellforsch. Mikrosk. Anat. 147: $335-352$.

Locke M., 1961. - Pore canals and related structures in insect cuticle. J. Biophys. Biochem. Cytol. $10: 589-619$.

Neville A. C., 1970. - Cuticle ultrastructure in relation to the whole insect. In : Insect Ultrastructure, A. C. Neville, ed. Roy. Entomol. Soc. Symp. 5 : 17-40. Oxford : Blackwells.

PIEK T., 1964. - Synthesis of wax in the honeybee (Apis mellifera L.). J. Insect Physiol. 10 : 563-572.

REYNolds E. S., 1963. - The use of lead citrate at high $\mathrm{pH}$ as an electron opaque stain in electron microscopy. J. Cell. Biol., $17: 208-212$.

Rieman K., 1952. -- Neue Untersuchungen über die Wachsdrüse der Honigbiene. Zool. Jahrb. (Anat.) $72: 251-272$.

Sмiтн D. S., 1968. - Insect cells. Edinburg : Oliver and Boyd. 372 p.

SPURR A. R., 1969. - A low-viscosity epoxy resin embedding medium for electron microscopy. J. Ultrastruct. Res. $26: 31-43$.

Talbot P., Clark, W. H. and A. L. Lawerence, 1972. - Light and electron microscopical studies on osmoregulatory tissue in the developing brown shrimp, Penaeus astecus. Tissue and Cell., $4: 271-286$.

Tullock A. P., 1970. - The composition of beeswax and other waxes secreted by insects. Lipids, $5: 247-258$.

Vergeron P., 1967. - La cire d'abeille, sa chimie et sa biosynthèse, son utilisation dans la ruche. Sci. Prog., 3391 : 428-432.

WICHARD W. and H. Komnick, 1971. - Electron microscopical and histochemical evidence of chloride cells in tracheal gills of mayfy larvae. Cytobiologie, $3: 215-228$.

Witkus E. R., Grillo R. S. and W. J. Sмith, 1969. - Microtubule bundles in the hindgut epithelium of the woodlouse Oniscus ascellus. J. Ultrastruct. Res., 29 : 182-190. 
PLATE I

FIG. 1. - Longitudinal view of wax secreting cuticle and the apex of the underlying epithelial cell. A thin epicuticle (Epi) is present, as are pore canals (Pc) made up of many wax filaments (Wf) which penetrate the procuticle (Pro). Microtubules (Mt) in the eytoplasm of the underlying cell can also be discerned.

Fig. 2. - Cross section of the cuticle revealing the slit-like pore canals (Pc) and tubular wax canal filaments (Wf).

FIg. 3. -- Longitudinal view of cytoplasm near the nucleus ( $N$ ) of the wax gland characterized by long microtubules (Mt), mitochondria (Mi) with tubular cristae and areas of rough endoplasmic reticulum ( $\operatorname{Rer})$.

FIG. 4. - Wax gland cell base and basal lamina (BI) in longitudinal section showing basal infoldings (Bi) filled with clear material (C). Apically the infoldings are filled with a more granular material (G). Mitochondria (Mi) and roughe ndoplasmic reticulum (Rer) are also seen.

FIG. 5. - Longitudinal view of apical portion of two wax gland cells. The granular material (G) is seen to penetrate the cytoplasm and concentrate below the cuticle (Cut). Tracheoles (T) also extend into the intercellular space. 

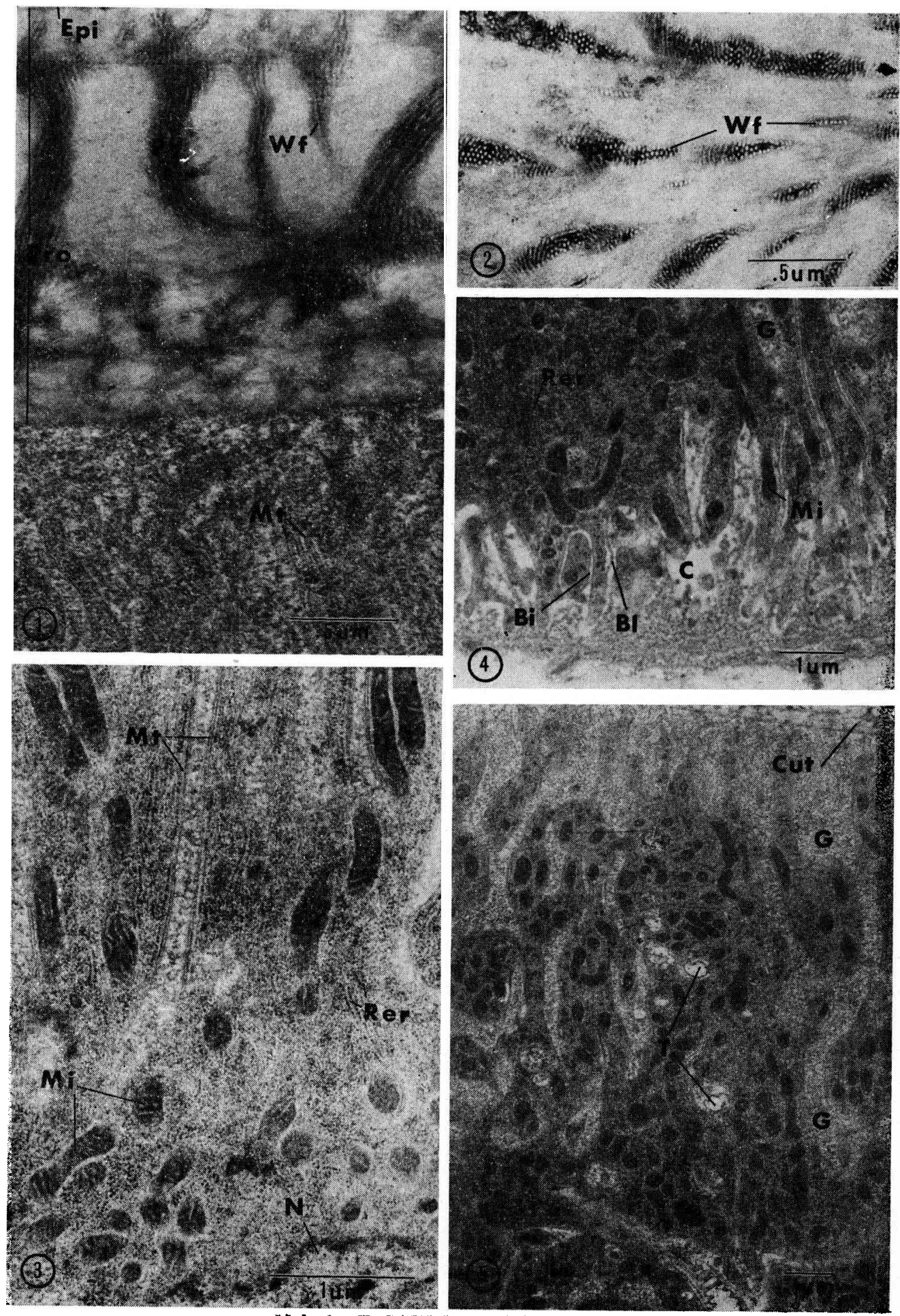

Malcolm T. SANFORD, Alfred DIETZ 


\section{PLATE II}

Fic. 6. - Nucleus (N) of a wax gland cell with three nucleoli (No), a cytoplasmic invagination (C) and nuclear pore $(\mathrm{Np})$.

Fig. 7. - An apparent tight junction $(\mathrm{Tj})$ between plasma membranes $(\mathrm{Pm})$ of two adjacent wax gland cells.

Fig. 8. - A desmosome (D) between two wax gland cells attaching the plasma membranes (Pm). Note the microtubules (Mt) in cross and longitudinal section. 

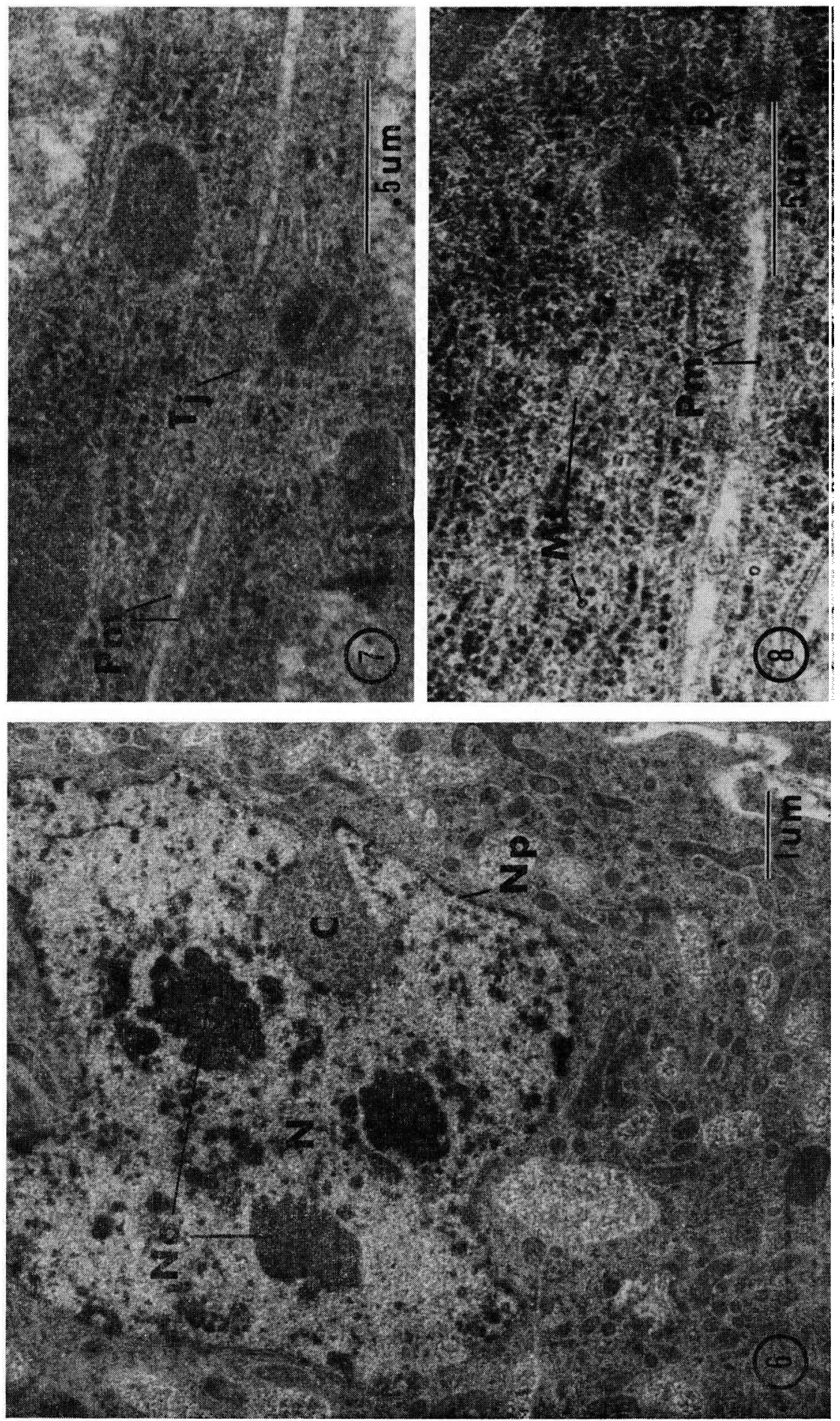